\title{
Innate endogenous adjuvants prime to desirable immune responses via mucosal routes
}

\author{
Xiaoguang Wang ${ }^{1,2 \bowtie}$, Delong Meng ${ }^{3}$ \\ ${ }^{1}$ CAS Key Laboratory of Pathogenic Microbiology and Immunology, Institute of Microbiology, Chinese Academy of Sciences, \\ Beijing 100101, China \\ 2 School of Biomolecular and Biomedical Science, University College Dublin, Dublin, Ireland \\ ${ }^{3}$ School of Biology and Environmental Science, University College Dublin, Dublin, Ireland \\ $\triangle$ Correspondence: wxg402@hotmail.com (X. Wang)
}

Received October 29, 2014 Accepted November 18, 2014

\begin{abstract}
Vaccination is an effective strategy to prevent infectious or immune related diseases, which has made remarkable contribution in human history. Recently increasing attentions have been paid to mucosal vaccination due to its multiple advantages over conventional ways. Subunit or peptide antigens are more reasonable immunogens for mucosal vaccination than live or attenuated pathogens, however adjuvants are required to augment the immune responses. Many mucosal adjuvants have been developed to prime desirable immune responses to different etiologies. Compared with pathogen derived adjuvants, innate endogenous molecules incorporated into mucosal vaccines demonstrate prominent adjuvanticity and safety. Nowadays, cytokines are broadly used as mucosal adjuvants for participation of signal transduction of immune responses, activation of innate immunity and polarization of adaptive immunity. Desired immune responses are promptly and efficaciously primed on basis of specific interactions between cytokines and corresponding receptors. In addition, some other innate molecules are also identified as potent mucosal adjuvants. This review focuses on innate endogenous mucosal adjuvants, hoping to shed light on the development of mucosal vaccines.
\end{abstract}

KEYWORDS mucosal vaccine, adjuvant, innate endogenous molecules

\section{INTRODUCTION}

Mucosal vaccination is the direct strategy against infections at the entry portal, where pathogens initiate infections via host mucosae. Compared with other vaccinated methods, mucosal vaccination is desirable for many reasons. Firstly the needle free application provides safety for the vaccinator, vaccinee and community, especially in developing countries (Giudice and Campbell, 2006). Cold chain free delivery reduces the cost on transportation and storage of vaccines. Easy manipulations of mucosal immunizations help to get rid of the dependence on vaccinators, which is flexible for vaccine administration. Moreover, mucosal immunizations increase the compliance with recommended vaccination schedules and reduce the side effects on vaccinee, especially children (Giudice and Campbell, 2006). The most distinct advantage of mucosal vaccination is that the speedy delivery to mucosal sites efficiently elicits mucosal immune responses, especially the secretion of mucosal IgA (Mcghee et al., 1992). Mucosal IgA is prominent to opsonise or neutralize mucosal pathogens and activate complement pathway at the portal of entry (Walker, 2004). In addition, mucosal vaccination also induces systemic immune responses, including serum IgG production and cell mediated responses on distal sites (Kaul and Ogra, 1998).

Mucosal surfaces are rich of immunologic organs, thus all mucosal sites are theoretically able to be used as vaccinated routes. On the basis of logical and practical considerations, oral and nasal routes are focused on the delivery of mucosal vaccines (Levine, 2003). Although oral administration of vaccines has been successfully used against polio, cholera and typhoid fever, intranasal delivery is the most effective way to induce potent and broad mucosal immune responses at multiple mucosal sites (Holmgren and Czerkinsky, 2005). Moreover, oral delivery of large amount of immunogens easily elicits oral tolerance and is challenged by stomach 
acids upon ingestion, inhibiting the usage of oral vaccines (Holmgren et al., 2003; Levine, 2003). The small surface area of nasal mucosa requires a low amount of antigens and the absence of acidity in nasal environment keeps the stability of antigens (De Magistnis, 2006).

Live or attenuated vaccines are efficient to control infectious diseases. However the safety concerns put live or attenuated vaccines to a debatable dilemma, which hinders the process of clinical applications. It is possible that vaccinated organisms may revert to wild-type or even hypervirulent organisms with its replication in the host. Therefore purified protective antigens were paid more attention to new generation mucosal vaccines. Direct mucosal administrations of soluble antigens only elicit relative low immunogenicity, thus safe and efficacious mucosal adjuvants are often co-administered with antigens to increase immunogenicity of non-living vaccines (De Magistnis, 2006). Furthermore, the adjuvant has been defined as immunopotentiator distinct from the delivery system previously (O'Hagan and Rappuoli, 2004).

Pathogen-derived adjuvants or derivatives have been widely used on the adjuvant system of mucosal vaccines. Although some adjuvants prime to potent and broad immune responses, the toxic threat and side effects of non-human products should be evaluated carefully. For example, a nasal enterotoxin-adjuvanted inactivated influenza vaccine was withdrawn after a short time in the market, due to the usage of adjuvant may cause facial paresis (Mutsch et al., 2004). Apparently the use of innate molecules as adjuvants is more advantageous than other compounds because of less toxicity of innate substances (Holmgren et al., 2003). The properties of the innate endogenous adjuvants in the development of mucosal vaccines for protection against infections will be extensively discussed in the following part.

\section{CYTOKINES}

Cytokines are loosely categorized as signaling proteins, which are released by a broad range of cells. The cytokine network activates and regulates the development of innate and adaptive immunity, balances the humoral and cell mediated immune responses. Thus they are critical in host defense against infections and modulation on immune related diseases (Dinarello, 2000). Immune responses could be initiated by simply adding these signaling molecules either as proteins or encoding DNAs (Holmgren et al., 2003; Cox et al., 2006), highlighting the potential adjuvanticity on vaccinations. A few cytokines in immune systems have been well studied and explored to enhance the vaccine efficacy.

\section{TYPE I IFNS}

Type I interferons (IFNs) have been considered as antiviral agents and primed the development of immune responses (Bracci et al., 2008). Several clinical reports clearly exhibits mucosal delivery of human IFN- $\alpha$ has direct prophylactic and therapeutic effects on cancers, autoimmune diseases and infections caused by influenza virus, RSV, measles virus, papillomavirus, HIV and hepatitis virus (Beilharz et al., 2010). Genes encoding chemokines, cytokines and proteases were significantly up-regulated with mucosal administration of type I IFNs, which are closely associated with antigen processing and lymphocyte activation, migration, apoptosis and protein degradation (Tovey, 2002; Namangala et al., 2006; Tovey et al., 2008). The treatment of IFN- $\alpha / \beta$ increased the antigenuptake rate of resident APCs in nasal mucus layer of mice (Bracci et al., 2005). Mucosal administration of IFN-a in low dose efficaciously activated the proliferation of natural killer cells, B cells and T-cell subpopulations in the peripheral circulation (Beilharz et al., 2010). Type I IFNs play the critical signaling role in some well researched adjuvants, including Th1 and CTL polarized types (Proietti et al., 2002; McBride et al., 2006). On the other hand, mucosal application of type I IFNs as immune suppressor efficaciously induces suppressor T cells, and reduces cytotoxic T cells and related cytokine products when encountering autoimmune and inflammatory diseases (Beilharz et al., 2010). Oro-mucosal administration of murine IFN- $\alpha$ significantly reduced the production of allergen specific $\lg E$ and the recruitment of eosinophil without detectable toxicity in mice (Meritet et al., 2001).

Intranasal administration of IFN- $\alpha / \beta$ with an influenza vaccine invoked an efficient humoral response, preventing mice from live influenza virus infection and weight loss (Proietti et al., 2002; Bracci et al., 2005; Bracci et al., 2006). Mice immunized with murine type I IFN and influenza virus $A$ vaccine presented high level of serum and mucosal antibodies, associated with efficacious virus clearance in the lung (Couch et al., 2009). However human trials exhibited that neither serum hemagglutination-inhibiting nor neutralizing antibody responses was significantly elevated in the presence of murine type I IFN. The mortality of mice challenged with lethal dose of influenza virus was significantly reduced by intranasal delivery of murine IFN- $\beta$ and inactivated influenza vaccine (Cao et al., 1992). Oral administration of murine type I IFN significantly elevated the survival of mice challenged systemically with a lethal dose of encephalomyocarditis virus, vesicular stomatitis virus or varicella zoster virus (Tovey and Maury, 1999). Intranasal immunization with vaccinia virus co-expressing interferon- $\varepsilon$ elevated lung VV-specific $\mathrm{CD}^{+} \mathrm{CD}^{+} 107 \mathrm{a}^{+} \quad \mathrm{IFN}^{-\mathrm{y}^{+}}$population, enhanced lymphocyte recruitment to lung alveoli with reduced inflammation and heightened functional/cytotoxic $\mathrm{CD}^{+} \mathrm{CD}^{+}{ }^{+}$-cell subset $\left(\mathrm{CD} 3^{\text {hi }} \mathrm{CCR} 7^{\text {hi }} \mathrm{CD} 6 \mathrm{~L}^{\mathrm{lo}}\right)$ in murine lung lymph nodes, corresponding to a rapid $\mathrm{V} V$ clearance in lungs (Wijesundara et al., 2014).

The immuostimulatory effects of type I IFNs are critically dependent upon the timing and dosage of mucosal administration (Beilharz et al., 2010). For instance, IFNs given prior to immunogen suppressed immunoglobulin production and class switching of B cells. Additionally, the high dose of type I IFNs was immunosuppressive. Meanwhile type I IFNs are regarded as immunosuppressors under the circumstances 
of autoimmune and inflammatory diseases. Some reports showed the administration of type I IFNs was detrimental to pathogen clearance (Wijesundara et al., 2014). Thus to illustrate the enigmatic roles of type I IFNs as immunomodulators or immunosuppressors requires further work on, but not limited, delivery sites, regulating mechanism, optimal dosages and schedules of type I IFNs, and disease indications and circumstances.

\section{IFN-Y}

IFN-y, produced primarily by T cells and NK cells in response to antigens or mitogens, plays a critical role in T-cell activation and the establishment of the adaptive immunity (Weaver et al., 2007). Intranasal delivery of murine IFN-Y and inactivated influenza vaccine increased survival of mice challenged with lethal dose of influenza virus (Cao et al., 1992). Further analysis showed the titers of $\lg A$ and $\lg G$ antibodies from IFN- $\gamma$ integrated group were enhanced at the early stage of infection, and the titer of $\mathrm{HI}$ antibody in the same group was significantly lower than that in mice given vaccine alone at the late stage of infection. Oral administration of murine IFN-y significantly elevated the survival of mice challenged systemically with a lethal dose of encephalomyocarditis virus (Tovey and Maury, 1999).

Both systemic and mucosal antigen specific $\lg G 1$ and $\lg A$ antibodies were enhanced by intranasal co-delivery of polyL-lactide microencapsulated $\mathrm{V}$ antigen of Yersinia pestis and IFN-y, however this formulation was detrimental to prevent infections by systemic bacterial challenge in the murine model (Griffin et al., 2002). A low dose of murine IFN-y was provided in drinking water to adult HAM/ICR mice, following challenged with Salmonella typhimurium one day later. In comparison with control mice, the application of IFN-y significantly prolonged survival time and reduced the penetration of Salmonellae into intestinal epithelial cells, development of bacteremia and mortality rate (Degre and Bukholm, 1995). Like type I IFNs, the dosage and immune schedule of IFN-y should be optimized in mucosal treatment since adverse effects were observed in some reports.

\section{GM-CSF}

Granulocyte macrophage-colony stimulating factor (GMCSF) enhances the recruitment and activation of APCs (Scheerlinck, 2001). Intranasal administration of human GMCSF enhanced serum GM-CSF levels and increased total leukocyte counts in rabbits (Watanabe et al., 1995). The levels of pulmonary APCs and cytokines, including IFN-Y and IL-12p40, were significantly elevated in mice administrated with recombinant RSV expressing murine GM-CSF intranasally (Bukreyev et al., 2001). Furthermore GM-CSFencoding virus shifted virus specific Th2 response to Th1 type. Intranasal co-administration of the HIV DNA vaccine with mouse GM-CSF-expressing plasmid induced high levels of systemic and mucosal antigen specific antibodies, and enhanced delayed type hypersensitivity in mice (Okada et al., 1997). Mice nasally co-immunized with adenovirus vectors encoding murine GM-CSF and amyloid $\beta$-protein exhibited predominant antigen specific IgG1 and IgG2b response, suggesting a GM-CSF polarized Th2 immune response (Kim et al., 2005). Recombinant vesicular stomatitis virus expressing murine GM-CSF was highly attenuated in terms of viral dissemination and pathogenesis (Ramsburg et al., 2005). Further analysis showed the addition of genetic GM-CSF enhanced the recruitment of macrophage, CD8 T-cell memory and recall responses in immunized mice.

Mice orally immunized with recombinant rabies viruses expressing GM-CSF exhibited higher number of DCs and B cells in the periphery, higher levels of adaptive immune responses and increased viral resistance than immunization with the parent virus (Zhou et al., 2013). The intranasal administration of GM-CSF expressing attenuated HSV induced protective immune responses against lethal dose challenge of HSV in mice (Parker et al., 2006). Pulmonary DC numbers and secretion of immunoregulatory cytokine IL-12 were significantly elevated by intranasal delivery of murine GM-CSF expressing Mycobacterium bovis BCG. (Nambiar et al., 2010). Correspondingly, antigen-specific $\mathrm{CD}^{+} \mathrm{T}$ cells increased in both mediastinal lymph nodes and lungs. More importantly, the administration of BCG:GM-CSF significantly reduced the load of infected $M$. tuberculosis compared with mice vaccinated with BCG alone. On the basis of above evidence, GM-CSF facilitates uptake of coadministrated antigens via the recruitment of APCs, thus priming immune responses.

\section{TNF FAMILY}

Tumor necrosis factor (TNF)/TNF receptor (TNFR) superfamily are critically involved in maintaining the homeostasis of the immune system, including beneficial and protective effects in inflammation and host defense (Kayamuro et al., 2009b). Intranasal co-administration of TNF- $\alpha$ along with antigen induced effective antigen-specific systemic IgG and mucosal IgA antibody responses in mice (Kayamuro et al., 2009a). Mucosal application of TNF- $\alpha$ primed to Th2-type immune responses by the analysis of cytokines. The adjuvant activity of TNF- $\alpha$ was proved to be efficacious and safe in mice and the adjuvanticity of TNF- $\alpha$ was associated, at least in part, with increased epithelial permeability. HIV immunogen adjuvanted with TNF- $\alpha$ mutant was used as a mucosal vaccine for induction of antigen specific serum IgG and local or distal mucosal $\lg \mathrm{A}$ antibody responses when the combination was administrated via the nasal route of mice (Kayamuro et al., 2010a). Other members of TNF family were also tested as mucosal adjuvants in the murine model (Kayamuro et al., 2011). Intranasal delivery of TL1A or APRIL with antigen induced strong antigen specific mucosal and humoral immune responses. Interestingly, the magnitude of immune responses elicited by TNFs was equivalent with that induced by CTB, indicating such candidates are promising to replace toxin-based adjuvants. 


\section{IL-1}

IL-1 secreted by various types of cells is a proinflammatory cytokine with a wide range of effects on the host immune system, including up- and down-regulations of many genes related with other cytokines, chemokines, adhesions, cell differentiations and migrations (Thompson and Staats, 2011). Mice nasally immunized with soluble antigens combined with human IL-1 $\alpha$ or IL-1 $\beta$ developed humoral and cell mediated immune responses, showing equivalent effect induced by co-administered antigens and CT adjuvant (Staats and Ennis, 1999). Ag-specific serum IgG, vaginal $\lg G$ and $\lg A$, systemic delayed-type hypersensitivity, and lymphocyte proliferative responses were significantly elevated with co-administration of antigens and IL-1 $\alpha$ or IL-1 $1 \beta$. Nasal administration of IL-1 $\alpha$ induced potent both systemic and mucosal innate immune responses in mice, dependent on IL-1R1 expression of stromal cells (Thompson et al., 2012). Moreover, the induction of adaptive immunity by IL-1 $\alpha$ is dependent on the CD11 $\mathrm{c}^{+}$cells. Murine IL-1 $\alpha$ exhibited significant adjuvant activity on the induction of HIV-specific serum IgG in mice with nasal route of immunization (Bradney et al., 2002). In addition, nasal immunization of murine IL-1 $\alpha$ and HIV immunogen induced significant CTL response and Ag-specific IFN- $y$-secreting cells in mice (Staats et al., 2001). Furthermore, intranasal delivery of human IL-1 $\alpha$ was proved to be safe and well tolerated in primate models (Egan et al., 2004). Tonsillar application of Streptococcus sobrinus protein antigens and human IL-1 elicited higher levels of both mucosal IgA and serum IgG antibodies than protein antigens alone (Kokuryo et al., 2002). Delayed type hypersensitivity to $S$. sobrinus, determined by ear swelling and increasing levels of IFN- $y$, was found to be induced only in rabbits immunized with IL-1.

The intranasal administration of murine $\mathrm{IL}-1 \alpha / \beta$ with influenza virus hemagglutinin (HA) provoked the increase of Th1- and Th2-type cytokines, systemic IgG and mucosal IgA (Kayamuro et al., 2010b). Moreover mice co-administrated with IL-1 $\alpha / \beta$ and HA were protected from the lethal infection of influenza virus. Nasal administration of human IL-1 $\beta$ adjuvant was as effective as subcutaneous immunization of alum adjuvant on the level of antibodies and protection against lethal dose challenge of Streptococcus pneumonia in mice (Gwinn et al., 2010). Like subcutaneous ISA-51 (a water-in-oil emulsion adjuvant) and nasal CTx adjuvants, $\mathrm{IL}-1 \beta$ was an efficacious nasal vaccine adjuvant for the induction of protective immunity against a systemic tetanus toxin challenge. Despite of efficacious adjuvanticity of IL-1, the pleiotropic characteristic of IL-1 easily elicits undesired immune responses, requiring well-defined optimized procedures to evaluate IL-1 as mucosal adjuvant.

\section{IL-2}

IL-2, mainly produced by naive T cells encountering antigens, contributes to the growth, proliferation and differentiation of $T$ cells during immune responses. By using live Lactococcus lactis as intranasal delivery vector, bacterial expression of murine IL-2 augmented the antigen (tetanus toxin fragment C) specific immune responses (Steidler et al., 1998). Meanwhile recombinant bacteria were not immunogenic in mice. HIV specific delayed type hypersensitivity response and CTL activity were enhanced in mice administrated with genetic murine IL-2 and antigen intranasally (Xin et al., 1998). Moreover DNA vaccination with the IL-2 expression plasmid induced a Th1 dominant immune response. Intranasally delivered plasmid encoding IL-2 shifted TT or CT induced Th2 type immune response to a Th1 type response (McNeela and Mills, 2001). The production of antigen specific IFN-y, IL-2 and IL-4 was augmented in mice orally administrated with plasmid expressing murine IL-2/lg (Wierzbicki et al., 2002). Furthermore high level of CTL activity and mucosal/serum antibodies were elicited in the approach of genetic IL-2/lg. Co-administration of inactivated avian influenza virus with IL-2 strongly enhanced the local immune response after intranasal immunization in a chicken model (Zhang et al., 2009). Recently, recombinant $B$. subtilis spores expressing a fragment of the Helicobacter acinonychis UreB protein elicited a strong cellular immune response in orally immunized mice when co-administered with spores expressing IL-2 (Hinc et al., 2014).

Subconjunctival delivery of genetic human IL-2-gD or peptide invoked efficacious neutralizing antibodies and cellular immune responses against HSV (Niethammer et al., 2001; Inoue et al., 2002). Further virus challenge showed the immunization of genetic IL-2-gD and peptide reduced the clinical scores and symptoms of Herpetic Keratitis in mice. In order to improve the efficacy of vaccination in old age population, IL-2 was incorporated into an attenuated, coldadapted influenza A virus. Intranasal immunization with human IL-2-expressing virus enhanced mucosal and cellular immune responses in both young and aged mice in comparison with administration of the parent strain (Ferko et al., 2006). More importantly, mice immunized with the IL-2expressing virus were completely protected against a lethal dose challenge of homologous influenza virus. A complicate immunized protocol was applied to the control of Simian/ Human Immunodeficiency Virus viremia. The nasal administration of genetic human IL-2 enhanced antigen specific cellular immune response, which provided long lasting protection from disease progression (Bertley et al., 2004).

Inclusion of human IL-2 into the intranasally administered liposomes containing bacterial polysaccharide from Aerobacter euanicum and Pseudomonas aeruginosa increased titers of bacterial polysaccharide specific slgA and pulmonary plasma cells (Abraham and Shah, 1992). Following analysis showed intranasal immunization with $P$. aeruginosa polysaccharide and IL-2 significantly reduced the murine mortality from $P$. aeruginosa pneumonia. Mucosal immunization of mice with recombinant $L$. lactis NZ9000 expressing the UreBe-IL-2 conjugated protein elicited more anti-UreB antibodies and more cytokines such as IFN- $\mathrm{y}, \mathrm{IL}-4$ and IL-17, 
and had a lower $H$. pylori burden and urease activity than control mice (Zhang et al., 2014). To sum up, both Th1 and Th2 immune responses are polarized by the mucosal application of IL-2, thus efficaciously preventing intracellular and extracellular infections.

\section{IL-4 AND IL-5}

Cytokine IL-4 induces the T cell differentiation from naive Th0 cells to Th2 cells, which subsequently produce additional IL-4 in a positive feedback loop. Furthermore, IL-4 participates into the proliferation of activated B-cell and T-cell, and the differentiation of B cells into plasma cells. High levels of systemic and mucosal antigen-specific antibodies were induced in mice immunized genetic HIV antigen and mouse IL-4 intranasally (Okada et al., 1997). Moreover, the IL-4 expression plasmid mainly induced IgG1 subtype in serum, however significantly suppressed the delayed type hypersensitivity and CTL response. Intranasal immunization of poly-L-lactide microencapsulated $\mathrm{V}$ antigen of $\mathrm{Y}$. pestis and IL-4 induced both systemic and mucosal antigen specific $\lg G$ and $\lg A$, however this combination vaccine reduced the survival of mice challenged with systemic bacterial injection (Griffin et al., 2002).

IL-5 produced by Th2 and mast cells stimulates B cell growth, increases immunoglobulin secretion and mediates eosinophil activation. Mice intranasally inoculated with adenovirus expressing murine IL-5 exhibited increased viral specific IgA titers in lung lavage fluid (Braciak et al., 2000). Correspondingly viral specific antibody-secreting cells presented high frequency in lung lymphocytes derived from mice immunized with IL-5 expressing adenovirus. The expression of IL-5 in a recombinant vaccinia virus vector significantly increased co-expressed heterologous antigen specific $\lg \mathrm{A}$ responses in the lungs of mice given intranasal inocula of the virus (Ramsay and Kohonencorish, 1993). Furthermore, the level of local IgA response to IL-5 administration peaked four-fold higher than that elicited by control virus at 14 days after infection, and was sustained for at least 4 weeks. As Th2 primed cytokines, mucosal administrations of IL-4 or IL-5 facilitate strong humoral immune responses.

\section{IL-6}

IL-6 is a pleiotropic cytokine that regulates both T and B cells (Vansnick, 1990). Tetanus toxin fragment C specific immune responses were primed and augmented by intranasal delivered Lactococcus lactis expressing murine IL-6, including serum IgG and mucosal IgA (Steidler et al., 1998). Intranasal inoculation of mice with adenovirus expressing murine IL-6 increased viral specific IgA/G titers in lung lavage fluid (Braciak et al., 2000). Viral specific antibody-secreting cells presented high frequency in lung lymphocytes derived from mice immunized with IL-6 expressing adenovirus. Histological analysis showed a large number of mononuclear cells had accumulated under the inoculation of plL-6. $\lg \mathrm{G} 1$ and $\lg \mathrm{A}$ antibodies were provoked by intranasal delivery of recombinant $\mathrm{V}$ antigen of $Y$. pestis coencapsulated with IL-6, contributing to full protection against systemic bacterial challenge to mice (Griffin et al., 2002). Nasal application of human IL-6 and tetanus toxin (TT) enhanced serum TT specific antibodies and Th2 response, protecting mice from lethal challenge with tetanus toxin (Boyaka et al., 1999). Oral administration of human IL-6 before oral infection with Campylobacter jejuni primed Campylobacter specific mucosal S-IgA Ab responses (Baqar et al., 1993). IL-6treated animals shed 3-log-unit reduction in the number of C. jejuni within $48 \mathrm{~h}$ of infection. Although cell mediated immune responses are rarely reported in mucosal application of IL-6, humoral immune responses are strongly activated in the presence of IL-6.

\section{IL-10}

One role of cytokine IL-10 is to down-regulate inflammations. Intranasal administration of genetic IL-10 diminished Aginduced delayed type hypersensitivity reactions in associated with the reduction of Ag-specific proliferation and production of Th1 cytokines in mice (Chun et al., 1999). Daily mucosal administration of $\mathrm{IL}-10$ secreting $L$. lactis reduces half symptoms of inductive or spontaneous murine colitis (Steidler et al., 2000). Comparing with intravenous injection, mucosal delivery required much lower dose of IL-10. Further study proved the efficacy and safety of mucosal delivery of human IL-10 secreting $L$. lactis on human trials (Braat et al., 2006). The incipient experimental allergic encephalomyelitis was suppressed in rats nasally administrated with autoantigen and human IL-10 (Xu et al., 2000). Following analysis showed that the approach of IL-10 decreased the proliferation of antigen-specific lymphocyte and antigen-reactive IFN-y secreting Th1-like cells. As an anti-inflammatory cytokine, adjuvant IL-10 is promising to control autoimmune or inflammatory diseases.

\section{IL-12}

IL-12, naturally produced by DC, macrophages and human B-lymphoblastoid cells, typically induces Th1 response and stimulates NK, T and B cells to produce IFN- $\gamma$ and TNF- $\alpha$ (Trinchieri, 1995; Watford et al., 2003). Consistently, mRNA transcripts of IFN- $\mathrm{Y}$ and IL-10 were elevated in mice immunized with murine IL-12 via nasal route (Arulanandam and Metzger, 1999). Intranasal co-administration of HIV genetic antigen and mouse IL-12-expressing plasmids induced both Th1- and Th2-type responses (Okada et al., 1997). Furthermore high levels of HIV-specific CTLs and delayed type hypersensitivity were enhanced in mice immunized with IL-12 and HIV antigen. Ovalbumin specific antibody levels of serum $\lg G 2 a, \lg G 2 b$ and $\lg G 3$ were significantly increased by IL-12 given intranasally, while serum IgG1 was suppressed. Incorporation of murine IL-12 to mice nasally immunized with the combined vaccine of TT and CT 
increased the secretion of TT-specific $\mathrm{CD}^{+} \mathrm{T}$ cells IFN-Y and reduced levels of Th2-type cytokines (i.e., IL-4, IL-5, IL-6 and $\mathrm{IL}-10$ ), implying the shift of CT-induced immune response toward Th1 type (Marinaro et al., 1999). However, IL-12 enhanced the Th2 type responses in mice given the combined vaccine orally. Murine IL-12 enhanced the production of $\mathrm{gD}$ (bovine herpesvirus type 1) specific IgA secreting cells, mucosal IgA/G and serum Ig $\mathrm{G}$ in intranasally vaccinated mice (Baca-Estrada et al., 1999).

Humoral and cellular responses were enhanced in mice intranasally administrated with plasmid DNA encoding murine IL-12 along with glycoprotein B (gB) DNA (Lee et al., 2003). Recipients of the co-immunization procedure showed greater resistance to vaginal challenge with a lethal dose of HSV-1. In another study, nasal delivery of murine IL-12 and influenza immunogens enhanced productions of both systemic and mucosal antibodies (Arulanandam et al., 1999). Mice immunized with antigen and IL-12 displayed decreased weight loss and significant enhanced survival after lethal dose challenge of influenza virus. The intranasal administration of murine IL-12 expressing attenuated HSV induced protective immune responses against lethal dose challenge of HSV to mice (Parker et al., 2006).

Mice intranasally administrated with murine IL-12 secreting and $E 7$ antigen expressing $L$. lactis were protected from the development of cervical cancer (Bermudez-Humaran et al., 2005). Humoral and mixed Th1/2 immune responses were enhanced in mice immunized with human IL-12 and tetanus toxin intranasally, providing full protection against lethal challenge with tetanus toxin (Boyaka et al., 1999). IL-12 as intranasal adjuvant efficiently prevented pneumococcal infection in murine models (Arulanandam et al., 2001; Lynch et al., 2003; Sun et al., 2007). Mucosal and systemic IgG2a and IgA were enhanced with the inclusion of IL-12, corresponding to the reduction of bacterial load. Intranasal administration of inactivated Francisella tularensis and murine IL-12 significantly increased the survival of mice under lethal intranasal challenge dose of $F$. tularensis (Baron et al., 2007). Neonatal mice vaccinated with pneumococcal polysaccharide conjugate vaccine and IL-12 exhibited enhanced IFN-y dependent mucosal and systemic immune responses to pneumococci, and vaccinated mice were efficiently prevented from both otitis media and invasive infection (Sabirov and Metzger, 2006). Moreover, the dose and toxicity of IL-12 was reduced by the intranasal route comparing with the parental administration route (Huber et al., 2003; Wright et al., 2011). Although IL-12 is regarded as Th1 type cytokine, mucosal application of IL-12 also induces strong Th2 immune responses.

\section{IL-15}

IL-15, mainly secreted by mononuclear phagocytes, induces cell proliferation of both innate and adaptive immune system such as natural killer cells and T cells (Shanmugham et al., 2006). Intranasal expression of murine IL-15 delivered by genetic sequence with HIV antigen increased the HIV-1specific delayed type hypersensitivity response and CTL activity, and decreased the serum $\lg 1 / \lg G 2 a$ ratio (Xin et al., 1999a). Moreover, murine lymphoid cells from mice administrated with genetic $\mathrm{IL}-15$ and antigen yielded increasing production of IFN-y and reducing secretion of IL-4. Intranasal administration of plasmid expressing murine IL-15 and FMDV antigen enhanced mucosal and systemic immune responses in animals (Wang et al., 2008). Mice immunized with IL-15 displayed high level of antigen-specific T-cell proliferation, CTL response and increased production of IFN-y in both $\mathrm{CD}^{+}$and $\mathrm{CD} 8^{+} \mathrm{T}$ cells isolated from the spleen and mucosal sites.

Mucosal administration of human IL-15 cDNA enhanced both humoral and cellular immune responses during memory phase of vaccinated mice (Toka et al., 2004; Toka and Rouse, 2005). Intravaginal challenge of HSV-1 showed the application of IL-15 enhanced the Th1-dependent HSV-1specific response, corresponding to a limited lesion severity and rapid elimination of the infecting virus from the distal mucosal site. Although mucosal administration of IL-15 and SIV vaccine preserved high levels of memory $\mathrm{CD}^{+}{ }^{+} \mathrm{T}$ cell numbers in rhesus macaques challenged with SIVmac251, the viral load was not reduced in the immunized group (Sui et al., 2011).

\section{IL-18}

IL-18 induces the activation of Th1, NK and CTL cells and production of IFN- $\gamma$, and regulates the synthesis of inflammatory cytokines, including IL-2 and IL-12 (Toka et al., 2004). Intranasal immunization of murine IL-18 and HIV immunogen induced significant CTL response and Ag-specific IFN- - -secreting cells in mice (Staats et al., 2001).

Antibody levels and IFN- $\gamma$ producing $T$ cell responses were enhanced in mice immunized with genetic murine IL-18 and antigen intranasally (Lee et al., 2003). The survival rate of mice immunized with genetic IL-18 and antigenic DNA increased against vaginal challenge with a lethal dose of HSV-1. The intranasal administration of murine IL-18 with HA induced the production of Th1- and Th2-type cytokines, systemic IgG and mucosal IgA (Kayamuro et al., 2010b). Moreover, high levels of CTL were elicited in the presence of $\mathrm{IL}-18$ and $\mathrm{HA}$, protecting mice against a lethal influenza virus infection. Further analysis showed the mucosal adjuvanticity of IL-18 was dependent on the activity of mast cells. Regarding the close association between activation of Th1 cells and IL-18, mucosal administration of IL-18 may be specific for preventing intracellular infections.

\section{FLT3L}

Fms-related tyrosine kinase 3 ligand (Flt3L) stimulates the proliferation and differentiation of various blood cell progenitors, including T cells, B cells, NK cells and DCs (Drexler and Quentmeier, 2004). OVA specific mucosal and plasma 
immune responses were significantly induced by intranasal administration of OVA and plasmid encoded murine Flt3L in comparison with OVA alone, leaning to a Th2 type (Kataoka et al., 2004). CD4 ${ }^{+} \mathrm{T}$ cells from the spleen and CLNs were highly proliferative and higher levels of IL-2 and IL-4 production were significantly accumulated in mice adjuvanted with Flt3L. The numbers of $C D 11 c^{+}$DCs in the mucosal effector sites, such as NPs, NALT and SMG, were remarkably enhanced due to nasal application of the expression plasmid encoding the Flt3L gene. Nasal administration of OVA and plasmid encoding mouse FIt3L enhanced OVAspecific mucosal and plasma antibodies and elicited Th2 immune response (Fukuiwa et al., 2008). Plasmacytoid DCs and $\mathrm{CD}^{+} \mathrm{DCs}$ were activated and expanded in the presence of plasmid encoding Flt3L. Mice nasally immunized with OVA and adenovirus expressing murine FIt3L exhibited high levels of OVA-specific mucosal and plasma antibodies as well as hyper-proliferation of OVA-specific $\mathrm{CD}^{+} \mathrm{T}$ cell and OVA-induced IFN- $\mathrm{Y}$ and IL-4 production in NALT, CLN and spleen (Sekine et al., 2008). OVA-specific CTL response was also enhanced in the spleen and CLN, and the number of $C D 11 b^{+} C D 11 c^{+}$DCs expressing high levels of costimulatory molecules was preferentially increased in NALT, which migrated to mucosal effector lymphoid tissues. A single intratracheal application of human Flt3L dose dependently increased $\mathrm{DC}$ and $\mathrm{T}$ lymphocytes $\left(\mathrm{CD}^{+}\right.$and $\left.\mathrm{CD}^{+}\right)$in rats, with a maximum on day 3 (Pabst et al., 2003). The cells in the lung interstitium and the bronchoalveolar space were affected by the administration of Flt3L, and subsequent intratracheal application of tetanus toxoid after the local Flt3L stimulation enhanced levels of antigen specific $\lg A$ and $\lg G$ in the lung.

Mice orally immunized with human Flt3L and CT were resistant to subsequent CT challenge in the model of ligated intestinal loops (Williamson et al., 1999). Flt3L-treated mice exhibited significantly elevated levels of CT-specific IgA Ab titers in both intestinal fluid and serum. The number of dendritic cells were increased in NALT with the nasal application of human Flt3L (Kodama et al., 2010). The coadministration of Flt3L and $\mathrm{P} 6$ protein of non-typeable Haemophilus influenzae induced $\mathrm{P} 6$-specific nasal wash $\lg \mathrm{A}$ and serum $\operatorname{lgG}$, antibody-producing cells and enhanced Haemophilus influenzae clearance from the nasopharynx in mice. Moreover, the longevity of vaccination was prolonged by nasal application of Flt3L and P6. Intranasal administration of pneumococcal surface protein $A(P s p A)$ and plasmid encoding the murine Flt3L increased levels of PspA-specific secretory $\lg A$ and $\lg \mathrm{Ab}$ responses that were correlated with elevated numbers of $\mathrm{CD}^{+}$and $\mathrm{CD} 11 \mathrm{~b}^{+} \mathrm{DCs}$ and IL-2and IL-4-producing CD4 ${ }^{+} \mathrm{T}$ cells in the NALT and CLNs (Kataoka et al., 2011). Correspondingly, numbers of CFU in the lungs, airway secretions and blood were markedly reduced when mice were nasally challenged with Streptococcus pneumoniae WU2. In conclusion, mucosal administration of Flt3L activates the interconnection between innate and adaptive immunity, which elicits both mucosal and systemic immune responses.

\section{CCR7 LIGANDS}

C-C chemokine receptor type 7 (CCR7) and its ligands direct the migration of mature DCs and establish a functional microenvironment to prime naive $T$ cells. A recent work demonstrated that intranasal administration of plasmid encoding murine Epstein-Barr virus-induced molecule 1 ligand chemokine (ELC) and HIV-1 gp140 significantly enhanced gp140-specific systemic and mucosal Ab responses in mice (Hu et al., 2013). Further analysis showed pELC co-delivery resulted in an increase of CCR $7^{+} \mathrm{CD} 11 \mathrm{c}^{+}$ cells in mesenteric lymph nodes and both $\mathrm{CCR} 7^{+} \mathrm{CD} 11 \mathrm{c}^{+}$ cells and $\mathrm{CCR} 7^{+} \mathrm{CD} 3 \mathrm{e}^{+}$cells in spleen.

Nasal and intragastric administration of genetic CCR7 ligands with herpes simplex virus 2 DNA plasmid stimulated distal mucosal $\lg A$ responses, and $\mathrm{CD}^{+} \mathrm{T}$ helper cell proliferation and $\mathrm{CD}^{+} \mathrm{T}$ cell-mediated CTL activity (Eo et al., 2001b). The number of dendritic cells was enhanced by co-delivery of CCR7 ligands in secondary lymphoid tissue. Secondary lymphoid tissue chemokine (SLC) specifically increased the production of Th1-type cytokines (IL-2 and IFN-y) and ELC elicited the yield of both Th1-type and Th2-type (IL-4) cytokines (Eo et al., 2001b). Further analysis showed co-delivery of CCR7 ligands with antigen generated a high CTL population that was capable of rapid expansion following infection with HSV (Toka et al., 2003). The symptom was relieved and the survival rate was increased in CCR7 ligands vaccinated mice under the lethal dose challenge of HSV McKrae strain. In summary, the migration of DCs induced by CCR7 ligands enhances the antigen uptake at mucosal sites and antigen presentation at lymphatic tissues, thus efficaciously inducing immune responses.

\section{MIPS AND MCPS}

Genetic application of $C C$ chemokines macrophage inflammatory protein $1 \beta$ (MIP-1 $\beta$ ) and monocyte chemotactic protein 1 (MCP-1) primed Th2-type immune response, while the CXC chemokine MIP-2 and the CC chemokine MIP-1 $1 \alpha$ elicited Th1-type pattern. Nasal approach of murine MIP-1 $\alpha$ elicited significant increases in anti-OVA IgG1 and IgG2b Ab titers followed by $\lg \mathrm{G} 2 \mathrm{a}$ and $\lg \mathrm{G} 3$ in mice (Lillard et al., 2003). Moreover, the production of IFN-y, Th1 and CD8 ${ }^{+}$ CTL responses were promoted in the presence of MIP-1 $1 \alpha$. Intranasal administration of murine MIP-1 $\beta$ induced antigen specific systemic $\lg G 1$ and $\lg G 2 b$ and mucosal $\lg A$. Both Th1 and Th2 responses were distinctively induced by MIP-1 $\beta$. Co-inoculation of murine MIP-1 $1 \alpha$ expressing plasmid and HIV DNA vaccine increased not only systemic and mucosal antibodies, but also CTL activity and delayed type hypersensitivity in mice (Lu et al., 1999). The low ratio between IgG1 and 
IgG2a indicated the dominated Th1 response in the presence of MIP-1 $\alpha$.

The function of antigen-presenting cells and expressions of costimulatory molecules (B7-1 and B7-2) were up-regulated in the presence of murine MIP-1a, whereas Th1-type $\mathrm{CD}^{+}$T-cell-mediated adaptive immunity was enhanced by murine MIP-2 via increasing secretion of IFN- $\gamma$ from activated NK cells (Eo et al., 2001a). In comparison with MIP-1 and MCP-1, mucosal genetic co-transfer of MIP-2 or MIP-1 $\alpha$ with genetic antigen rendered recipients (mice) more resistant to HSV intravaginal infection. Nasal application of MIP-3 $\alpha$ with P6 protein of nontypable Haemophilus influenzae (NTHi) induced an increase in the number of dendritic cells in murine NALT and P6-specific nasal wash IgA and serum IgG titers (Kodama et al., 2011). Accordingly, the clearance of NTHi was enhanced in MIP-3 $\alpha$ immunized group.

\section{RANTES}

RANTES (regulated on activation, normal T cell expressed and secreted) is an inflammatory chemokine that promotes the accumulation and activation of several types of leukocytes, including $\mathrm{CD}^{+} \mathrm{T}$ cells and macrophages (Baggiolini and Dahinden, 1994). Intravaginally co-administered murine RANTES-expressing plasmid (pRANTES) with antigen efficaciously expressed at the vaginal tissues, and induced more vaginal IgA and serum IgG immune responses than CT adjuvant in mice (Oh et al., 2003). Intranasal administration of plasmids carrying env and rev genes of HIV-1 and encoding murine RANTES induced significantly higher titers of serum HIV-1-specific IgG, IgG2a and fecal IgA antibodies than antigen DNA vaccination alone (Xin et al., 1999b). This vaccinated combination also increased HIV-1-specific CTL activity and delayed-type hypersensitivity in mice. Nasal coadministration of murine RANTES and the antigen initiated and enhanced Ag-specific humoral and cellular immune responses in both mucosal and systemic compartments (Lillard et al., 2001). Furthermore, nasal delivery of RANTES induced proliferative and Th1- (IL-2 and IFN- $y$ ) type responses, and RANTES was proved to up-regulate CD28, CD40L and CD30 expression on both resting and activated T lymphocytes. The unique T cell activation by RANTES may facilitate vaccinations to achieve desirable $T$ cell mediated immune responses.

\section{ANTIMICROBIAL MOLECULES}

As chemotactic antimicrobial peptides for T cells, defensins exert adjuvant activity on the induction of antigen-specific immune response by nasal co-administration with antigens. Antigen-specific $\lg \mathrm{G} 1$ followed by $\lg \mathrm{g} 2 \mathrm{~b}$ and $\lg \mathrm{G} 2 \mathrm{a}$ was promoted by addition with human defensins, indicating the development of both Th-1 and selected Th- 2 type immune responses. Furthermore, antigen specific $\mathrm{CD}^{+} \mathrm{Th}$ cell responses and cytokines of IL-5 and IL- 6 were observed in the presence of defensins, corresponding to the Th1 and Th2 responses (Lillard et al., 1999a). Nasally co-administered human neutrophil peptide (HNP) defensins with protein antigens enhanced systemic immunity, however HNPs provided inhibitory signals for mucosal $B$ and $T$ cells. Mice intranasally immunized with HNPs displayed antigen specific proliferative responses of $\mathrm{CD}^{+}$and high production of IFN-y, IL-5, IL-6 and IL-10, indicating HNPs elicited both Th1 and Th2 immune responses. In comparison with mice immunized with only OVA, human HNP-1, HBD1 and HBD2 induced significantly higher OVA-specific serum IgG, including IgG1 and IgG2b subtypes (Brogden et al., 2003). Moreover, the additive HNP-1, HNP-2 and HBD2 yielded lower IFN-Y and HBD1 enhanced the production of IL-10 in mice. Oral administration of cathelicidin LL-37 and conjugated antigen effectively evoked the antigen-specific systemic and mucosal immune responses, especially virus neutralization antibodies (Jang et al., 2013). Further analysis exhibited the number of germinal centers were significantly induced by chemotactic effect of LL-37 in both Peyer's patch and mesenteric lymph node. In addition, strong Th1- and Th17-skewed immune responses were elicited through $\mathrm{CD}_{11 \mathrm{c}^{+}} \mathrm{CD}^{+} \mathrm{O}^{+}$cell activation in Peyer's patch.

In comparison with BCG alone, delayed type hypersensitivity response was enhanced in mice orally administrated with lactoferrin and BCG (Chodaczek et al., 2006). Oral administration of lactoferrin increased the frequency of neutrophil precursors in the peripheral blood and decreased the spontaneous production of IL- 6 and TNF- $\alpha$ by unstimulated blood cell cultures in human trials (Kruzel and Zimecki, 2002). Furthermore, patients subjected to thyroid surgery were treated with lactoferrin, exhibiting increased immune responsiveness. Beside the direct inhibition on pathogens, above antimicrobial molecules are also efficacious mucosal adjuvants, attracting further experimental and clinical trials on vaccine development.

\section{OTHER INNATE MUCOSAL ADJUVANTS}

The above listed innate molecules have been well defined as mucosal adjuvants, however other endogenous molecules are reported to prime immune response with limited literatures. Lymphotactin (Lptn), belonging to $\mathrm{C}$ chemokine family, is predominantly produced by NK, CD8 ${ }^{+}$T cells and $ү \delta \mathrm{TCR}^{+}$ intraepithelial lymphocytes. Nasal administration of murine Lptn with protein antigens promoted both mucosal and systemic immunity (Lillard et al., 1999b). Mice immunized with antigen and Lptn displayed higher antigen-specific proliferative responses and increased synthesis of IFN- $\gamma$, IL-2, IL-4, IL-5, IL-6 and IL-10 of CD4 ${ }^{+} \mathrm{T}$ cells. This indicated that Lptn induced mixed Th1 and Th2-type responses. Eotaxin is a potent chemoattractant for eosinophils via the eotaxin receptor CCR-3. Intranasal administration of eotaxin caused chemotaxis of eosinophils with a clinically symptomatic inflammatory response in the human nasal mucosa, 
which was accompanied with the increase of nasal NO, contributing to oxidative stress (Hanazawa et al., 2000). Thymic stromal lymphopoietin acted as a potent mucosal adjuvant for HIV-1 gp140 vaccination in mice (Van Roey et al., 2012). The use of murine TSLP as an adjuvant skewed both the cellular and humoral immune responses towards Th2 cells in mice.

The intranasal administration of murine IL-33 with HA induced the production of Th1- and Th2-type cytokines, systemic IgG and mucosal IgA (Kayamuro et al., 2010b). Nasal approach of IL-33 and HA induced high levels of CTL, efficaciously protecting mice against a lethal influenza virus infection. Like IL-18, some activity of IL-33 is related to mast cells. B-cell activating factor (BAFF) secreted by stromal cells is crucial for survival and maturation of $B$ cells (Batten et al., 2000; Kalled, 2006). Antigen specific systemic/mucosal antibodies were significantly enhanced in mice administrated with replication-deficient adenovirus vector expressing murine BAFF and heat-killed $P$. aeruginosa intranasally, reducing murine mortality under lethal dose challenge of $P$. aeruginosa (Tertilt et al., 2009). Moreover the spatial and temporal proximity with antigens were unnecessary for the application of BAFF as the immune booster.

\section{COMBINED INNATE ENDOGENOUS ADJUVANTS}

Although many innate endogenous molecules are evaluated as mucosal vaccine adjuvants, combined adjuvants are required to induce desired immune responses. Coadministration of the DNA vaccine with murine IL-12- and GM-CSF-expressing plasmids induced high levels of HIVspecific antibodies (Okada et al., 1997). Moreover, CTLs and delayed type hypersensitivity were increased when both chemokines were administered to mice intranasally. Intranasal administration of adenovirus encoding murine IL-5 and IL-6 acted additively to enhance local mucosal $\lg A$ and $\lg$ antibody responses (Braciak et al., 2000). Correspondingly viral specific antibody-secreting cells presented high frequency in lung lymphocytes derived from mice immunized with IL-5 and IL-6 expressing adenovirus.

Combinations of two or three cytokines including murine IL-1 $\alpha, I L-12, I L-18$ and GM-CSF plus HIV immunogen efficaciously enhanced mucosal IgA, induced CTL lytic activities, increased Ag-specific IFN- $\mathrm{Y}$-secreting splenic cells and $\mathrm{CD}^{+}$in the peripheral blood (Staats et al., 2001). The antipeptide serum IgG and mucosal IgA titers were significantly induced by the combination of immunogens with multiple murine cytokines, e.g. IL-1a, IL-12 and IL-18 or IL-1a, IL-12 and GM-CSF (Bradney et al., 2002). Combination of human IL-1 $\alpha$ and GM-CSF with antigen increased both mucosal and systemic antibodies by intranasal vaccinated route in macaques (Egan et al., 2004). The level of anti-DNP tear $\lg \mathrm{A}$ was significantly enhanced in the lymphokine-treated rats co-administrated with antigen and murine IL-5 and IL-6
(Pockley and Montgomery, 1991). Rhesus macaques intranasally immunized with vaccinia virus Ankara carrying SIV DNA and plasmid expressing IL-2 and IL-15 or GM-CSF, IL-12 and TNF- $\alpha$ exhibited significant SIV-specific mucosal and systemic cell-mediated immunity (Manrique et al., 2011). Both vaccinated formulations significantly reduced the viral titer after intravaginal SIVmac251 challenge, corresponding to long survival time.

\section{CONCLUSIONS AND PERSPECTIVES}

This review briefly describes the applications of innate endogenous molecules on developing mucosal adjuvants. The incorporation of these molecules significantly reduces the dose of antigens, enhances strong mucosal and systemic antibodies, elicits cell mediated immune response and eventually provides protections against pathogens or immune related diseases. The safety would be increased by the application of endogenous molecules instead of bacteria derived or synthetic materials. The mucosal route of vaccine delivery has been considered for a number of reasons including direct targeting of sites where the effects of given antigen or adjuvant are needed. Interestingly, some noncurable or recurrent infectious diseases could be effectively controlled by mucosal vaccinations as summarized in Table 1.

Cytokines are broadly used as mucosal adjuvants on the basis of their intrinsic characteristics, participating signal transduction of immune responses, activation of innate immunity and polarization of adaptive immunity. In use of the specific interactions between cytokines and corresponding receptors, desired immune responses are promptly and efficaciously primed. The relatively short half-life of recombinant homologues of cytokines has limited their use as vaccine adjuvants. These difficulties have been overcome by encapsulation into liposomes, virosomes and microparticles, and the use of cytokine expressing vectors co-administered with DNA vaccines. Moreover, the approach of DNA vaccines reduces the cost and increases the duration time of vaccinations. Beside cytokines, some other innate molecules are also identified as potent mucosal adjuvants recently.

Although some encouraging results on mucosal adjuvants have been achieved with different cytokines, important adverse effects are often associated with the large and repeated cytokine doses. Additionally, most cytokines are pleiotropic on the immune responses, sometimes eliciting unnecessary immune responses. The principle will be essential for rationally selecting vaccine adjuvants and application doses that induce potent immune responses in the absence of undesired effects. The homologies between human and non-human endogenous molecules vary differently, which affects the adjuvanticity in cross testing systems. Most innate mucosal adjuvants are evaluated on animal models, requiring further human trials for safety and efficacy of these potent molecules. 
Table 1. Summary of innate endogenous adjuvants on mucosal immunization against HIV, HSV and influenza virus infections

\begin{tabular}{|c|c|c|c|c|}
\hline Etiologies & Antigens & Adjuvants & Outcomes & References \\
\hline \multirow[t]{13}{*}{ HIV } & $\begin{array}{l}\text { Plasmid encoding env } \\
\text { gp160 and rev genes }\end{array}$ & $\begin{array}{l}\text { Plasmid encoding } \\
\text { GM-CSF }\end{array}$ & $\begin{array}{l}\text { Increase antibodies, enhance } \\
\text { delayed type hypersensitivity }\end{array}$ & Okada et al. 1997 \\
\hline & gp120 & TNF- $\alpha$ & Increase levels of antibodies & Kayamuro et al. $2010 a$ \\
\hline & $\mathrm{C} 4-\mathrm{V} 3_{\mathrm{IIIB}}$ and $\mathrm{C} 4-\mathrm{V} 3_{\mathrm{MN}}$ & $\mathrm{IL}-1 \alpha$ & $\begin{array}{l}\text { Increase antibodies and } \\
\text { cellular immune responses }\end{array}$ & Staats et al. 2001 \\
\hline & $\begin{array}{l}\text { Plasmid encoding HIV- } \\
1_{\mathrm{IIIB}} \text { env and rev }\end{array}$ & Plasmid encoding IL-2 & $\begin{array}{l}\text { Enhance Th1 dominant } \\
\text { immune response }\end{array}$ & Xin et al. 1998 \\
\hline & $\begin{array}{l}\text { Plasmid encoding env } \\
\text { gp160 and rev genes }\end{array}$ & $\begin{array}{l}\text { Plasmid encoding IL-4 } \\
\text { or IL-12 }\end{array}$ & $\begin{array}{l}\text { Enhance Th1- and Th2-type } \\
\text { responses and production of } \\
\text { antibodies }\end{array}$ & Okada et al. 1997 \\
\hline & $\begin{array}{l}\text { Plasmid encoding HIV- } \\
1_{\text {IIIB }} \text { env and rev }\end{array}$ & Plasmid encoding IL-15 & $\begin{array}{l}\text { Increase the delayed type } \\
\text { hypersensitivity response } \\
\text { and CTL activity }\end{array}$ & Xin et al. $1999 a$ \\
\hline & $\mathrm{C} 4-\mathrm{V} 3_{\mathrm{IIIB}}$ and $\mathrm{C} 4-\mathrm{V} 3_{\mathrm{MN}}$ & IL-18 & $\begin{array}{l}\text { Induce CTL response and Ag- } \\
\text { specific IFN- }- \text {-secreting cells }\end{array}$ & Staats et al. 2001 \\
\hline & $\begin{array}{l}\text { Plasmid encoding } \\
\text { gp140 }\end{array}$ & Plasmid encoding ELC & $\begin{array}{l}\text { Elicit systemic and mucosal Ab } \\
\text { responses }\end{array}$ & Hu et al. 2013 \\
\hline & $\begin{array}{l}\text { Plasmid encoding } \\
\text { gp160 and rev }\end{array}$ & Plasmid encoding MIP-1 $\alpha$ & $\begin{array}{l}\text { Increase antibodies, CTL } \\
\text { activity and delayed type } \\
\text { hypersensitivity }\end{array}$ & Lu et al. 1999 \\
\hline & $\begin{array}{l}\text { Plasmids expressing } \\
\text { env and rev genes }\end{array}$ & $\begin{array}{l}\text { Plasmid encoding } \\
\text { RANTES }\end{array}$ & $\begin{array}{l}\text { Increase antibodies, CTL } \\
\text { activity and delayed-type } \\
\text { hypersensitivity }\end{array}$ & Xin et al. $1999 b$ \\
\hline & gp140 & $\begin{array}{l}\text { Thymic stromal } \\
\text { lymphopoietin }\end{array}$ & $\begin{array}{l}\text { Facilitate cellular and humoral } \\
\text { immune responses }\end{array}$ & Van Roey et al. 2012 \\
\hline & $\begin{array}{l}\text { Plasmid encoding env } \\
\text { gp160 and rev genes }\end{array}$ & $\begin{array}{l}\text { Plasmid encoding } \\
\text { IL12 + GM-CSF }\end{array}$ & $\begin{array}{l}\text { Increase antibodies, CTL } \\
\text { activity and delayed-type } \\
\text { hypersensitivity }\end{array}$ & Okada et al. 1997 \\
\hline & $\mathrm{C} 4-\mathrm{V} 3_{\mathrm{IIIB}}$ and $\mathrm{C} 4-\mathrm{V} 3_{\mathrm{MN}}$ & $\begin{array}{l}\mathrm{IL}-1 \alpha, \mathrm{IL}-12, \mathrm{IL}-18 \\
\text { and GM-CSF }\end{array}$ & $\begin{array}{l}\text { Enhance CTL response and } \\
\text { Ag-specific IFN- } \mathrm{Y} \text {-secreting } \\
\text { cells }\end{array}$ & Staats et al. 2001 \\
\hline \multirow[t]{7}{*}{ HSV } & Attenuated HSV & $\begin{array}{l}\text { Attenuated HSV } \\
\text { expressing GM-CSF } \\
\text { or IL-12 }\end{array}$ & $\begin{array}{l}\text { Protection against lethal dose } \\
\text { viral challenge }\end{array}$ & Parker et al. 2006 \\
\hline & $\mathrm{gD}$ & $\mathrm{IL}-2$ & $\begin{array}{l}\text { Enhance humoral and cellular } \\
\text { immune responses, reduce } \\
\text { the clinical scores and } \\
\text { symptoms of Herpetic } \\
\text { Keratitis }\end{array}$ & $\begin{array}{l}\text { Niethammer et al. 2001; } \\
\text { Inoue et al. } 2002\end{array}$ \\
\hline & Plasmid encoding gB & Plasmid encoding IL-12 & $\begin{array}{l}\text { Induce humoral and cellular } \\
\text { immune responses, } \\
\text { protection against lethal dose } \\
\text { challenge }\end{array}$ & Lee et al. 2003 \\
\hline & Plasmid encoding gB & Plasmid encoding IL-15 & $\begin{array}{l}\text { Enhance the Th1-dependent } \\
\text { response and rapid } \\
\text { elimination of virus }\end{array}$ & $\begin{array}{l}\text { Toka et al. } 2004 \text {; Toka and } \\
\text { Rouse } 2005\end{array}$ \\
\hline & $g B$ & Plasmid encoding IL-18 & $\begin{array}{l}\text { Increase antibody levels, IFN-y } \\
\text { producing } T \text { cell responses } \\
\text { and survival rate }\end{array}$ & Lee et al. 2003 \\
\hline & $\mathrm{gB}$ & CCR7 ligands & $\begin{array}{l}\text { Increase CTL population and } \\
\text { survival rate }\end{array}$ & Toka et al. 2003 \\
\hline & Plasmid encoding gB & $\begin{array}{l}\text { Plasmid encoding MIP-2 } \\
\text { or MIP-1a }\end{array}$ & $\begin{array}{l}\text { Enhance cellular immune } \\
\text { responses and protect from } \\
\text { HSV challenge }\end{array}$ & Eo et al. 2001a \\
\hline
\end{tabular}


Table 1 continued

\begin{tabular}{|c|c|c|c|c|}
\hline Etiologies & Antigens & Adjuvants & Outcomes & References \\
\hline \multirow[t]{7}{*}{$\begin{array}{l}\text { Influenza } \\
\text { virus }\end{array}$} & $\begin{array}{l}\text { Monovalent subunit } \\
\text { influenza vaccine } \\
\text { "Agrippal" } \\
\text { IVR-116 }\end{array}$ & IFN- $\alpha / \beta$ & $\begin{array}{l}\text { Enhance humoral responses, } \\
\text { prevent mice from live } \\
\text { influenza virus infection and } \\
\text { weight loss }\end{array}$ & $\begin{array}{l}\text { Proietti et al. 2002; } \\
\text { Bracci et al. 2005, } 2006\end{array}$ \\
\hline & $\begin{array}{l}\text { Inactivated monovalent } \\
\text { A/Texas/91 (H1N1) } \\
\text { vaccine }\end{array}$ & Type I IFN & $\begin{array}{l}\text { Elicit high levels of antibodies, } \\
\text { efficacious viral clearance }\end{array}$ & Couch et al. 2009 \\
\hline & $\begin{array}{l}\text { Inactivated influenza } \\
\text { vaccine }\end{array}$ & IFN- $\beta$ & Increase survival rate & Cao et al. 1992 \\
\hline & $\begin{array}{l}\text { HA derived from } \\
\text { influenza virus } A / \mathrm{New} \\
\text { Caledonia/20/1999 }\end{array}$ & IL- $1 \alpha / \beta$ or IL-18 or IL-33 & $\begin{array}{l}\text { Enhance antibodies levels and } \\
\text { survival rate }\end{array}$ & Kayamuro et al. $2010 \mathrm{~b}$ \\
\hline & $\begin{array}{l}\text { Inactivated Influenza } \\
\text { virus A/Ostrich/ } \\
\text { Denmark/72420/96 }\end{array}$ & IL-2 & $\begin{array}{l}\text { Enhance mucosal immune } \\
\text { responses }\end{array}$ & Zhang et al. 2009 \\
\hline & $\begin{array}{l}\text { Influenza virus ca } \\
\text { A/Sing/57-NS1_87 }\end{array}$ & Virus expressing IL-2 & $\begin{array}{l}\text { Enhance mucosal and cellular } \\
\text { immune responses, protect } \\
\text { mice from lethal dose viral } \\
\text { challenge }\end{array}$ & Ferko et al. 2006 \\
\hline & $\begin{array}{l}\text { HA and N1A purified } \\
\text { from influenza virus } \\
\text { A/PR8/34 }\end{array}$ & IL-12 & $\begin{array}{l}\text { Increase mucosal and } \\
\text { systemic antibodies, protect } \\
\text { mice from lethal dose viral } \\
\text { challenge }\end{array}$ & Arulanandam et al. 1999 \\
\hline
\end{tabular}

\section{ABBREVIATIONS}

CCR7, CC chemokine receptor type 7; ELC, Epstein-Barr virusinduced molecule 1 ligand chemokine; Flt3L, Fms-related tyrosine kinase 3 ligand; gB, glycoprotein B; GM-CSF, granulocyte macrophage-colony stimulating factor; HA, hemagglutinin; HNP, human neutrophil peptide; IFNs, interferons; MCP-1, monocyte chemotactic protein 1 ; MIP-1 $\beta$, macrophage inflammatory protein $1 \beta$; PspA, pneumococcal surface protein $A$; SLC, secondary lymphoid tissue chemokine; TNF, tumor necrosis factor; TT, tetanus toxin.

\section{COMPLIANCE WITH ETHICS GUIDELINES}

Xiaoguang Wang and Delong Meng declare that they have no conflict of interest.

This article does not contain any studies with human or animal subjects performed by the any of the authors.

\section{OPEN ACCESS}

This article is distributed under the terms of the Creative Commons Attribution License which permits any use, distribution, and reproduction in any medium, provided the original author(s) and the source are credited.

\section{REFERENCES}

Abraham E, Shah S (1992) Intranasal immunization with liposomes containing IL-2 enhances bacterial polysaccharide antigen-specific pulmonary secretory antibody-response. J Immunol 149:3719-3726
Arulanandam BP, Metzger DW (1999) Modulation of mucosal and systemic immunity by intranasal interleukin 12 delivery. Vaccine 17:252-260

Arulanandam BP, O'Toole M, Metzger DW (1999) Intranasal interleukin-12 is a powerful adjuvant for protective mucosal immunity. $\mathrm{J}$ Infect Dis 180:940-949

Arulanandam BP, Lynch JM, Briles DE, Hollingshead S, Metzger DW (2001) Intranasal vaccination with pneumococcal surface protein A and interleukin-12 augments antibody-mediated opsonization and protective immunity against Streptococcus pneumoniae infection. Infect Immun 69:6718-6724

Baca-Estrada ME, Foldvari M, Snider M (1999) Induction of mucosal immune responses by administration of liposomeantigen formulations and interleukin-12. J Interferon Cytokine Res 19:455-462

Baggiolini M, Dahinden CA (1994) CC chemokines in allergic inflammation. Immunol Today 15:127-133

Baqar S, Pacheco ND, Rollwagen FM (1993) Modulation of mucosal immunity against Campylobacter jejuni by orally-administered cytokines. Antimicrob Agents Chemother 37:2688-2692

Baron SD, Singh R, Metzger DW (2007) Inactivated Francisella tularensis live vaccine strain protects against respiratory tularemia by intranasal vaccination in an immunoglobulin A-dependent fashion. Infect Immun 75:2152-2162

Batten M, Groom J, Cachero TG, Qian F, Schneider P, Tschopp J, Browning JL, Mackay F (2000) BAFF mediates survival of peripheral immature B lymphocytes. J Exp Med 192:1453-1465

Beilharz MW, Cummins MJ, Bennett AL, Cummins JM (2010) Oromucosal administration of interferon to humans. Pharmaceuticals 3:323-344 
Bermudez-Humaran LG, Cortes-Perez NG, Lefevre F, Guimaraes V, Rabot S, Alcocer-Gonzalez JM, Gratadoux JJ, Rodriguez-Padilla C, Tamez-Guerra RS, Corthier G et al (2005) A novel mucosal vaccine based on live lactococci expressing $\mathrm{E} 7$ antigen and IL-12 induces systemic and mucosal immune responses and protects mice against human papillomavirus type 16-induced tumors. J Immunol 175:7297-7302

Bertley FMN, Kozlowski PA, Wang SW, Chappelle J, Patel J, Sonuyi O, Mazzara G, Montefiori D, Carville A, Mansfield KG et al (2004) Control of simian/human immunodeficiency virus viremia and disease progression after IL-2-augmented DNA-modified vaccinia virus Ankara nasal vaccination in nonhuman primates. J Immunol 172:3745-3757

Boyaka PN, Marinaro M, Jackson RJ, Menon S, Kiyono H, Jirillo E, McGhee JR (1999) IL-12 is an effective adjuvant for induction of mucosal immunity. J Immunol 162:122-128

Braat $H$, Rottiers P, Hommes DW, Huyghebaert N, Remaut E, Remon JP, Van Deventer SJH, Neirynck S, Peppelenbosch MP, Steidler L (2006) A phase I trial with transgenic bacteria expressing interleukin-10 in Crohn's disease. Clin Gastroenterol Hepatol 4:754-759

Bracci L, Canini I, Puzelli S, Sestili P, Venditti M, Spada M, Donatelli I, Belardelli F, Proietti E (2005) Type I IFN is a powerful mucosal adjuvant for a selective intranasal vaccination against influenza virus in mice and affects antigen capture at mucosal level. Vaccine 23:2994-3004

Bracci L, Canini I, Venditti M, Spada M, Puzelli S, Donatelli I, Belardelli F, Proietti E (2006) Type I IFN as a vaccine adjuvant for both systemic and mucosal vaccination against influenza virus. Vaccine 24:S56-S57

Bracci L, La Sorsa V, Belardelli F, Proietti E (2008) Type I interferons as vaccine adjuvants against infectious diseases and cancer. Expert Rev Vaccines 7:373-381

Braciak TA, Gallichan WS, Graham FL, Richards CD, Ramsay AJ, Rosenthal KL, Gauldie J (2000) Recombinant adenovirus vectors expressing interleukin-5 and -6 specifically enhance mucosal immunoglobulin A responses in the lung. Immunology 101:388396

Bradney CP, Sempowski GD, Liao HX, Haynes BF, Staats HF (2002) Cytokines as adjuvants for the induction of anti-human immunodeficiency virus peptide immunoglobulin $G(\lg G)$ and $\lg A$ antibodies in serum and mucosal secretions after nasal immunization. J Virol 76:517-524

Brogden KA, Heidari M, Sacco RE, Palmquist D, Guthmiller JM, Johnson GK, Jia HP, Tack BF, McCray PB (2003) Defensininduced adaptive immunity in mice and its potential in preventing periodontal disease. Oral Microbiol Immunol 18:95-99

Bukreyev A, Belyakov IM, Berzofsky JA, Murphy BR, Collins PL (2001) Granulocyte-macrophage colony-stimulating factor expressed by recombinant respiratory syncytial virus attenuates viral replication and increases the level of pulmonary antigenpresenting cells. J Virol 75:12128-12140

Cao M, Sasaki O, Yamada A, Imanishi J (1992) Enhancement of the protective effect of inactivated influenza virus vaccine by cytokines. Vaccine 10:238-242

Chodaczek G, Zimecki M, Lukasiewicz J, Lugowski C (2006) A complex of lactoferrin with monophosphoryl lipid $A$ is an efficient adjuvant of the humoral and cellular immune response in mice. Med Microbiol Immunol 195:207-216

Chun S, Daheshia M, Lee S, Eo SK, Rouse BT (1999) Distribution fate and mechanism of immune modulation following mucosal delivery of plasmid DNA encoding IL-10. J Immunol 163:23932402

Couch RB, Atmar RL, Cate TR, Quarles JM, Keitel WA, Arden NH, Wells J, Nino D, Wyde PR (2009) Contrasting effects of type I interferon as a mucosal adjuvant for influenza vaccine in mice and humans. Vaccine 27:5344-5348

Cox E, Verdonck F, Vanrompay D, Goddeeris B (2006) Adjuvants modulating mucosal immune responses or directing systemic responses towards the mucosa. Vet Res 37:511-539

De Magistnis MT (2006) Mucosal delivery of vaccine antigens and its advantages in pediatrics. Adv Drug Deliv Rev 58:52-67

Degre M, Bukholm G (1995) Orally administered interferon-gamma but not tumor necrosis factor-alpha suppress infection with Salmonella typhimurium in a mouse model. J Biol Regul Homeost Agents 9:15-20

Dinarello CA (2000) Proinflammatory cytokines. Chest 118:503-508

Drexler HG, Quentmeier H (2004) FLT3: receptor and ligand. Growth Factors 22:71-73

Egan MA, Chong SY, Hagen M, Megati S, Schadeck EB, Piacente P, Ma BJ, Montefiori DC, Haynes BF, Israel ZR et al (2004) A comparative evaluation of nasal and parenteral vaccine adjuvants to elicit systemic and mucosal HIV-1 peptide-specific humoral immune responses in cynomolgus macaques. Vaccine 22:3774-3788

Eo SK, Lee S, Chun S, Rouse BT (2001a) Modulation of immunity against herpes simplex virus infection via mucosal genetic transfer of plasmid DNA encoding chemokines. J Virol 75:569578

Eo SK, Lee S, Kumaraguru U, Rouse BT (2001b) Immunopotentiation of DNA vaccine against herpes simplex virus via co-delivery of plasmid DNA expressing CCR7 ligands. Vaccine 19:46854693

Ferko B, Kittel C, Romanova J, Sereinig S, Katinger H, Egorov A (2006) Live attenuated influenza virus expressing human interleukin-2 reveals increased immunogenic potential in young and aged hosts. J Virol 80:11621-11627

Fukuiwa T, Sekine S, Kobayashi R, Suzuki H, Kataoka K, Gilbert RS, Kurono Y, Boyaka PN, Krieg AM, McGhee JR et al (2008) A combination of Flt3 ligand $\mathrm{CDNA}$ and $\mathrm{CpG}$ ODN as nasal adjuvant elicits NALT dendritic cells for prolonged mucosal immunity. Vaccine 26:4849-4859

Giudice EL, Campbell JD (2006) Needle-free vaccine delivery. Adv Drug Deliv Rev 58:68-89

Griffin KF, Eyles JE, Spiers ID, Alpar HO, Williamson ED (2002) Protection against plague following immunisation with microencapsulated $\mathrm{V}$ antigen is reduced by co-encapsulation with IFNgamma or IL-4, but not IL-6. Vaccine 20:3650-3657

Gwinn WM, Kirwan SM, Wang SH, Ashcraft KA, Sparks NL, Doil CR, Tlusty TG, Casey LS, Hollingshead SK, Briles DE et al (2010) Effective induction of protective systemic immunity with nasally administered vaccines adjuvanted with IL-1. Vaccine 28:6901-6914

Hanazawa T, Antuni JD, Kharitonov SA, Barnes PJ (2000) Intranasal administration of eotaxin increases nasal eosinophils and nitric 
oxide in patients with allergic rhinitis. J Allergy Clin Immunol 105:58-64

Hinc K, Stasilojc M, Piatek I, Peszynska-Sularz G, Isticato R, Ricca E, Obuchowski M, Iwanicki A (2014) Mucosal adjuvant activity of IL-2 presenting spores of Bacillus subtilis in a murine model of Helicobacter pylori vaccination. Plos One 9:e95187

Holmgren J, Czerkinsky C (2005) Mucosal immunity and vaccines. Nat Med 11:S45-S53

Holmgren J, Czerkinsky C, Eriksson K, Mharandi A (2003) Mucosal immunisation and adjuvants: a brief overview of recent advances and challenges. Vaccine 21:S89-S95

Hu K, Luo S, Tong L, Huang X, Jin W, Huang W, Du T, Yan Y, He S, Griffin GE et al (2013) CCL19 and CCL28 augment mucosal and systemic immune responses to HIV-1 gp140 by mobilizing responsive immunocytes into secondary lymph nodes and mucosal tissue. J Immunol 191:1935-1947

Huber VC, Arulanandam BP, Arnaboldi PM, Elmore MK, Sheehan CE, Kallakury BV, Metzger DW (2003) Delivery of IL-12 intranasally leads to reduced IL-12-mediated toxicity. Int Immunopharmacol 3:801-809

Inoue $\mathrm{T}$, Inoue $\mathrm{Y}$, Nakamura $\mathrm{T}$, Yoshida A, Inoue $\mathrm{Y}$, Tano $\mathrm{Y}$, Shimomura Y, Fujisawa Y, Aono A, Hayashi K (2002) The effect of immunization with herpes simplex virus glycoprotein $D$ fused with interleukin-2 against murine herpetic keratitis. Jpn J Ophthalmol 46:370-376

Jang YS, Kim SH, Lee HY, Lee H, Kim J, Kim DH, Lee KY (2013) The cathelicidin LL-37 exerts its mucosal adjuvant activity via enhancing germinal center formation and dendritic cell maturation. J Immunol 190:124

Kalled SL (2006) Impact of the BAFF/BR3 axis on B cell survival, germinal center maintenance and antibody production. Semin Immunol 18:290-296

Kataoka K, McGhee JR, Kobayashi R, Fujihashi K, Shizukuishi S, Fujihashi K (2004) Nasal Flt3 ligand cDNA elicits CD11c(+)CD8 $(+)$ dendritic cells for enhanced mucosal immunity. J Immunol 172:3612-3619

Kataoka K, Fujihashi K, Oma K, Fukuyama Y, Hollingshead SK, Sekine S, Kawabata S, Ito HO, Briles DE, Oishi K (2011) The nasal dendritic cell-targeting Flt3 ligand as a safe adjuvant elicits effective protection against fatal pneumococcal pneumonia. Infect Immun 79:2819-2828

Kaul D, Ogra PL (1998) Mucosal responses to parenteral and mucosal vaccines. Dev Biol Stand 95:141-146

Kayamuro H, Abe Y, Yoshioka Y, Katayama K, Nomura T, Yoshida T, Yamashita K, Yoshikawa T, Kawai Y, Mayumi Tet al (2009a) The use of a mutant TNF-alpha as a vaccine adjuvant for the induction of mucosal immune responses. Biomaterials 30:5869-5876

Kayamuro H, Yoshioka Y, Abe Y, Katayama K, Yoshida T, Yamashita K, Yoshikawa T, Hiroi T, Itoh N, Kawai $Y$ et al (2009b) TNF superfamily member, TL1A, is a potential mucosal vaccine adjuvant. Biochem Biophys Res Commun 384:296-300

Kayamuro H, Abe Y, Yoshioka Y, Katayama K, Yoshida T, Yamashita K, Yoshikawa T, Kawai Y, Mayumi T, Hiroi T et al (2010a) Mutant TNF-alpha, mTNF-K90R, is a novel candidate adjuvant for a mucosal vaccine against HIV. Pharmazie 65:254-256

Kayamuro H, Yoshioka Y, Abe Y, Arita S, Katayama K, Nomura T, Yoshikawa T, Kubota-Koketsu R, Ikuta K, Okamoto $S$ et al (2010b) Interleukin-1 family cytokines as mucosal vaccine adjuvants for induction of protective immunity against influenza virus. J Virol 84:12703-12712

Kayamuro H, Yoshioka Y, Abe Y, Katayama K, Arita S, Nomura T, Yoshikawa T, Itoh N, Kamada H, Tsunoda S et al (2011) Identification of new candidates as mucosal vaccine adjuvant in TNF family cytokines. In: Advances in TNF family research, Springer New York, pp 299-304

Kim HD, Cao YP, Kong FK, Van Kampen KR, Lewis TL, Ma ZD, Tang DCC, Fukuchi KI (2005) Induction of a Th2 immune response by co-administration of recombinant adenovirus vectors encoding amyloid beta-protein and GM-CSF. Vaccine 23:2977-2986

Kodama S, Hirano T, Noda K, Abe N, Suzuki M (2010) A single nasal dose of fms-like tyrosine kinase receptor-3 ligand, but not peritoneal application, enhances nontypeable Haemophilus influenzae-specific long-term mucosal immune responses in the nasopharynx. Vaccine 28:2510-2516

Kodama S, Abe N, Hirano T, Suzuki M (2011) A single nasal dose of CCL20 chemokine induces dendritic cell recruitment and enhances nontypable Haemophilus influenzae-specific immune responses in the nasal mucosa. Acta Otolaryngol 131:989-996

Kokuryo S, Inoue H, Fukuizumi T, Tsujisawa T, Tominaga K, Fukuda $J(2002)$ Evaluation of interleukin 1 as a mucosal adjuvant in immunization with Streptococcus sobrinus cells by tonsillar application in rabbits. Oral Microbiol Immunol 17:163-171

Kruzel ML, Zimecki M (2002) Lactoferrin and immunologic dissonance: Clinical implications. Arch Immunol Ther Exp 50:399-410

Lee S, Gierynska M, Eo SK, Kuklin N, Rouse BT (2003) Influence of DNA encoding cytokines on systemic and mucosal immunity following genetic vaccination against herpes simplex virus. Microbes Infect 5:571-578

Levine MM (2003) Can needle-free administration of vaccines become the norm in global immunization? Nat Med 9:99-103

Lillard JW, Boyaka PN, Chertov O, Oppenheim JJ, McGhee JR (1999a) Mechanisms for induction of acquired host immunity by neutrophil peptide defensins. Proc Natl Acad Sci USA 96:651656

Lillard JW, Boyaka PN, Hedrick JA, Zlotnik A, McGhee JR (1999b) Lymphotactin acts as an innate mucosal adjuvant. J Immunol 162:1959-1965

Lillard JW, Boyaka PN, Taub DD, McGhee JR (2001) RANTES potentiates antigen-specific mucosal immune responses. J Immunol 166:162-169

Lillard JW Jr, Singh UP, Boyaka PN, Singh S, Taub DD, McGhee JR (2003) MIP-1alpha and MIP-1beta differentially mediate mucosal and systemic adaptive immunity. Blood 101:807-814

Lu Y, Xin KQ, Hamajima K, Tsuji T, Aoki I, Yang J, Sasaki S, Fukushima J, Yoshimura T, Toda S et al (1999) Macrophage inflammatory protein-1 alpha (MIP-1 alpha) expression plasmid enhances DNA vaccine-induced immune response against HIV1. Clin Exp Immunol 115:335-341

Lynch JM, Briles DE, Metzger DW (2003) Increased protection against pneumococcal disease by mucosal administration of conjugate vaccine plus interleukin-12. Infect Immun 71:47804788

Manrique M, Kozlowski PA, Cobo-Molinos A, Wang SW, Wilson RL, Montefiori DC, Mansfield KG, Carville A, Aldovini A (2011) Long- 
term control of simian immunodeficiency virus (mac251) viremia to undetectable levels in half of infected female rhesus macaques nasally vaccinated with simian immunodeficiency virus DNA/ recombinant modified vaccinia virus ankara. J Immunol 186:3581-3593

Marinaro M, Boyaka PN, Jackson RJ, Finkelman FD, Kiyono $\mathrm{H}$, Jirillo E, McGhee JR (1999) Use of intranasal IL-12 to target predominantly Th1 responses to nasal and Th2 responses to oral vaccines given with cholera toxin. J Immunol 162:114-121

McBride S, Hoebe K, Georgel P, Janssen E (2006) Cell-associated double-stranded RNA enhances antitumor activity through the production of type IIFN. J Immunol 177:6122-6128

Mcghee JR, Mestecky J, Dertzbaugh MT, Eldridge JH, Hirasawa M, Kiyono $H$ (1992) The mucosal immune system from fundamental concepts to vaccine development. Vaccine 10:75-88

McNeela EA, Mills KHG (2001) Manipulating the immune system: humoral versus cell-mediated immunity. Adv Drug Deliver Rev 51:43-54

Meritet JF, Maury C, Tovey MG (2001) Effect of oromucosal administration of IFN-alpha on allergic sensitization and the hypersensitive inflammatory response in animals sensitized to ragweed pollen. J Interferon Cytokine Res 21:583-593

Mutsch M, Zhou WG, Rhodes P, Bopp M, Chen RT, Linder T, Spyr C, Steffen R (2004) Use of the inactivated intranasal influenza vaccine and the risk of Bell's palsy in Switzerland. New Engl $J$ Med 350:896-903

Namangala B, Inoue N, Kohara J, Kuboki N, Sakurai T, Hayashida K, Sugimoto C (2006) Evidence for the immunostimulatory effects of low-dose orally delivered human IFN-alpha in cattle. J Interferon Cytokine Res 26:675-681

Nambiar JK, Ryan AA, Kong CU, Britton WJ, Triccas JA (2010) Modulation of pulmonary DC function by vaccine-encoded GMCSF enhances protective immunity against Mycobacterium tuberculosis infection. Eur J Immunol 40:153-161

Niethammer AG, Xiang R, Ruehlmann JM, Lode HN, Dolman CS, Gillies SD, Reisfeld RA (2001) Targeted interleukin 2 therapy enhances protective immunity induced by an autologous oral DNA vaccine against murine melanoma. Cancer Res 61:61786184

Oh YK, Park JS, Yoon H, Kim CK (2003) Enhanced mucosal and systemic immune responses to a vaginal vaccine coadministered with RANTES-expressing plasmid DNA using in situ-gelling mucoadhesive delivery system. Vaccine 21:1980-1988

O'Hagan DT, Rappuoli R (2004) Novel approaches to vaccine delivery. Pharm Res 21:1519-1530

Okada E, Sasaki S, Ishii N, Aoki I, Yasuda T, Nishioka K, Fukushima J, Miyazaki J, Wahren B, Okuda K (1997) Intranasal immunization of a DNA vaccine with IL-12- and granulocyte-macrophage colony-stimulating factor (GM-CSF)-expressing plasmids in liposomes induces strong mucosal and cell-mediated immune responses against HIV-1 antigens. J Immunol 159:3638-3647

Pabst R, Luhrmann A, Steinmetz I, Tschernig T (2003) A single intratracheal dose of the growth factor Fms-like tyrosine kinase receptor-3 ligand induces a rapid differential increase of dendritic cells and lymphocyte subsets in lung tissue and bronchoalveolar lavage, resulting in an increased local antibody production. J Immunol 171:325-330
Parker JN, Pfister LA, Quenelle D, Gillespie GY, Markert JM, Kern ER, Whitley RJ (2006) Genetically engineered herpes simplex viruses that express IL-12 or GM-CSF as vaccine candidates. Vaccine 24:1644-1652

Pockley AG, Montgomery PC (1991) In vivo adjuvant effect of interleukins 5 and 6 on rat tear $\lg A$ antibody responses. Immunology 73:19-23

Proietti E, Bracci L, Puzelli S, Di Pucchio T, Sestili P, De Vincenzi E, Venditti M, Capone I, Seif I, De Maeyer E et al (2002) Type I IFN as a natural adjuvant for a protective immune response: lessons from the influenza vaccine model. J Immunol 169:375-383

Ramsay AJ, Kohonencorish M (1993) Interleukin-5 expressed by a recombinant virus vector enhances specific mucosal IgA responses in vivo. Eur J Immunol 23:3141-3145

Ramsburg E, Publicover J, Buonocore L, Poholek A, Robek M, Palin A, Rose JK (2005) A vesicular stomatitis virus recombinant expressing granulocyte-macrophage colony-stimulating factor induces enhanced T-cell responses and is highly attenuated for replication in animals. J Virol 79:15043-15053

Sabirov A, Metzger DW (2006) Intranasal vaccination of neonatal mice with polysaccharide conjugate vaccine for protection against pneumococcal otitis media. Vaccine 24:5584-5592

Scheerlinck JPY (2001) Genetic adjuvants for DNA vaccines. Vaccine 19:2647-2656

Sekine S, Kataoka K, Fukuyama Y, Adachi Y, Davydova J, Yamamoto M, Kohayashi R, Fujihashi K, Suzuki H, Curiel DT et al (2008) A novel adenovirus expressing Flt3 ligand enhances mucosal immunity by inducing mature nasopharyngeal-associated lymphoreticular tissue dendritic cell migration. J Immunol 180:8126-8134

Shanmugham LN, Petrarca C, Frydas S, Donelan J, Castellani ML, Boucher W, Madhappan B, Tete S, Falasca K, Conti P et al (2006) IL-15 an immunoregulatory and anti-cancer cytokine. Recent advances. J Exp Clin Cancer Res 25:529-536

Staats HF, Ennis FA (1999) IL-1 is an effective adjuvant for mucosal and systemic immune responses when coadministered with protein immunogens. J Immunol 162:6141-6147

Staats HF, Bradney CP, Gwinn WM, Jackson SS, Sempowski GD, Liao HX, Letvin NL, Haynes BF (2001) Cytokine requirements for induction of systemic and mucosal CTL after nasal immunization. J Immunol 167:5386-5394

Steidler L, Robinson K, Chamberlain L, Schofield KM, Remaut E, Le Page RW, Wells JM (1998) Mucosal delivery of murine interleukin-2 (IL-2) and IL-6 by recombinant strains of Lactococcus lactis coexpressing antigen and cytokine. Infect Immun 66:3183-3189

Steidler L, Hans W, Schotte L, Neirynck S, Obermeier F, Falk W, Fiers W, Remaut E (2000) Treatment of murine colitis by Lactococcus lactis secreting interleukin-10. Science 289:1352-1355

Sui Y, Gagnon S, Dzutsev A, Zhu Q, Yu H, Hogg A, Wang Y, Xia Z, Belyakov IM, Venzon D et al (2011) TLR agonists and/or IL-15 adjuvanted mucosal SIV vaccine reduced gut CD4(+) memory $T$ cell loss in SIVmac251-challenged rhesus macaques. Vaccine 30:59-68

Sun K, Salmon SL, Lotz SA, Metzger DW (2007) Interleukin-12 promotes gamma interferon-dependent neutrophil recruitment in the lung and improves protection against respiratory Streptococcus pneumoniae infection. Infect Immun 75:1196-1202 
Tertilt C, Joh J, Krause A, Chou PG, Schneeweiss K, Crystal RG, Worgall S (2009) Expression of B-cell activating factor enhances protective immunity of a vaccine against $P$ seudomonas aeruginosa. Infect Immun 77:3044-3055

Thompson AL, Staats HF (2011) Cytokines: the future of intranasal vaccine adjuvants. Clin Dev Immunol 2011:289597

Thompson AL, Johnson BT, Sempowski GD, Gunn MD, Hou B, DeFranco AL, Staats HF (2012) Maximal adjuvant activity of nasally delivered IL-1 alpha requires adjuvant-responsive CD11C $(+)$ cells and does not correlate with adjuvant-induced in vivo cytokine production. J Immunol 188:2834-2846

Toka FN, Rouse BT (2005) Mucosal application of plasmid-encoded IL-15 sustains a highly protective anti-Herpes simplex virus immunity. J Leukoc Biol 78:178-186

Toka FN, Gierynska M, Rouse BT (2003) Codelivery of CCR7 ligands as molecular adjuvants enhances the protective immune response against herpes simplex virus type 1. J Virol 77:12742-12752

Toka FN, Pack CD, Rouse BT (2004) Molecular adjuvants for mucosal immunity. Immunol Rev 199:100-112

Tovey MG (2002) Oromucosal cytokine therapy: mechanism(s) of action. Taehan Kan Hakhoe Chi 8:125-131

Tovey MG, Maury C (1999) Oromucosal interferon therapy: marked antiviral and antitumor activity. J Interferon Cytokine Res 19:145155

Tovey MG, Lallemand C, Thyphronitis G (2008) Adjuvant activity of type I interferons. Biol Chem 389:541-545

Trinchieri G (1995) Interleukin-12: a proinflammatory cytokine with immunoregulatory functions that bridge innate resistance and antigen-specific adaptive immunity. Annu Rev Immunol 13:251-276

Van Roey GA, Arias MA, Tregoning JS, Rowe G, Shattock RJ (2012) Thymic stromal lymphopoietin (TSLP) acts as a potent mucosal adjuvant for HIV-1 gp140 vaccination in mice. Eur $\mathrm{J}$ Immunol 42:353-363

Vansnick J (1990) Interleukin-6: an overview. Annu Rev Immunol 8:253-278

Walker DM (2004) Oral mucosal immunology: an overview. Ann Acad Med Singap 33:27-30

Wang X, Zhang XY, Kang YM, Jin HL, Du XG, Zhao G, Yu Y, Li JY, Su BW, Huang $C$ et al (2008) Interleukin-15 enhance DNA vaccine elicited mucosal and systemic immunity against foot and mouth disease virus. Vaccine 26:5135-5144

Watanabe $\mathrm{Y}$, Matsumoto $\mathrm{Y}$, Kikuchi R, Kiriyama M, Nakagawa K, Nomura H, Maruyama K, Matsumoto M (1995) Pharmacokinetics and pharmacodynamics of recombinant human granulocyte colony-stimulating factor (rhG-CSF) following intranasal administration in rabbits. J Drug Targ 3:231-238

Watford WT, Moriguchi M, Morinobu A, O'Shea JJ (2003) The biology of IL-12: coordinating innate and adaptive immune responses. Cytokine Growth Factor Rev 14:361-368
Weaver CT, Hatton RD, Mangan PR, Harrington LE (2007) IL-17 family cytokines and the expanding diversity of effector $\mathrm{T}$ cell lineages. Annu Rev Immunol 25:821-852

Wierzbicki A, Kiszka I, Kaneko H, Kmieciak D, Wasik TJ, Gzyl J, Kaneko Y, Kozbor D (2002) Immunization strategies to augment oral vaccination with DNA and viral vectors expressing HIV envelope glycoprotein. Vaccine 20:1295-1307

Wijesundara DK, Xi Y, Ranasinghe C (2014) Unraveling the convoluted biological roles of type I interferons in infection and immunity: a way forward for therapeutics and vaccine design. Front Immunol 5:412

Williamson E, Westrich GT, Viney JL (1999) Modulating dendritic cells to optimize mucosal immunization protocols. J Immunol 163:3668-3675

Wright AKA, Christopoulou I, El Batrawy S, Limer J, Gordon SB (2011) rhlL-12 as adjuvant augments lung cell cytokine responses to pneumococcal whole cell antigen. Immunobiology 216:1143-1147

Xin KQ, Hamajima K, Sasaki S, Honsho A, Tsuji T, Ishii N, Cao XR, Lu Y, Fukushima J, Shapshak $P$ et al (1998) Intranasal administration of human immunodeficiency virus type-1 (HIV-1) DNA vaccine with interleukin-2 expression plasmid enhances cellmediated immunity against HIV-1. Immunology 94:438-444

Xin KQ, Hamajima K, Sasaki S, Tsuji T, Watabe S, Okada E, Okuda K (1999a) IL-15 expression plasmid enhances cell-mediated immunity induced by an HIV-1 DNA vaccine. Vaccine 17:858-866

Xin KQ, Lu Y, Hamajima K, Fukushima J, Yang J, Inamura K, Okuda K (1999b) Immunization of RANTES expression plasmid with a DNA vaccine enhances HIV-1-specific immunity. Clin Immunol 92:90-96

Xu LY, Yang JS, Huang YM, Levi M, Link H, Xiao BG (2000) Combined nasal administration of encephalitogenic myelin basic protein peptide $68-86$ and IL-10 suppressed incipient experimental allergic encephalomyelitis in Lewis rats. Clin Immunol 96:205211

Zhang X, Yu Q, Zhang X, Yang Q (2009) Co-administration of inactivated avian influenza virus with $\mathrm{CpG}$ or rIL-2 strongly enhances the local immune response after intranasal immunization in chicken. Vaccine 27:5628-5632

Zhang HX, Qu YY, Zhao YH, Liu XT, Liu M, Yu AL (2014) Immunogenicity of oral vaccination with Lactococcus lactis derived vaccine candidate antigen (UreB) of Helicobacter pylon fused with the human interleukin 2 as adjuvant. Mol Cell Probes 28:25-30

Zhou M, Zhang G, Ren G, Gnanadurai CW, Li Z, Chai Q, Yang Y, Leyson CM, Wu W, Cui M et al (2013) Recombinant rabies viruses expressing GM-CSF or flagellin are effective vaccines for both intramuscular and oral immunizations. PLoS One 8:e63384 